\title{
Why French Academic Journals are Protesting
}

\section{Collective of journals joined in struggle and Camille Noûs}

Translator. Jean-Yves Bart

\section{(2) OpenEdition}

\section{Journals}

Electronic version

URL: http://journals.openedition.org/bssg/368

DOI: $10.4000 /$ bssg.368

ISSN: 2490-9424

\section{Publisher}

Presses universitaires de Vincennes

Electronic reference

Collective of journals joined in struggle and Camille Noûs, "Why French Academic Journals are Protesting", Biens Symboliques / Symbolic Goods [Online], 5 | 2019, Online since 09 March 2020, connection on 04 March 2021. URL: http://journals.openedition.org/bssg/368 ; DOI: https://doi.org/ 10.4000/bssg.368

This text was automatically generated on 4 March 2021.

Biens Symboliques / Symbolic Goods 


\title{
Why French Academic Journals are Protesting
}

\author{
Collective of journals joined in struggle and Camille Noûs \\ Translation : Jean-Yves Bart
}

\section{Revues en lutte}

1 Since the beginning of $2020^{1}$, over a hundred academic journals, mostly French human and social sciences publications, have announced that they have "joined the struggle" or that they are "on strike". Their editorial boards have teamed up with the ongoing social movement protesting the plans to overhaul the country's pension system, the unemployment benefits reform of November 2019 and the proposals formulated in the reports for the upcoming law for the pluriannual programming of research known as $\mathrm{LPPR}^{2}$. In its extent and its form - strikes and votes on motions in which editorial boards have abandoned their customary reserve - this is a historically unprecedented mobilization. A collective dynamic has swept the community, beyond disciplinary boundaries, schools and the working conditions of individual journals, reflecting the widespread uproar sparked by these reforms. For higher education and research, the pension reform devised by the government in its current state will lead to heightened inequalities across the board (between men and women, between permanent and shortterm staff, etc.) and to impoverishment for all, civil servants, contract workers and precarious staff. The unemployment benefits reform is also expected to exacerbate the already great vulnerability of the very large numbers of precarious workers who contribute extensively to the day-to-day operations of universities and laboratories: they account for over $25 \%$ of teaching staff and far greater proportions of support staff. The LPPR research law will only make the lack of resources, of positions and of stability worse, and deepen the inequalities that have been undermining higher education and reform, amplified by two decades of massively protested "reforms". 


\section{Manufacturing the crisis of the public service of research and universities}

2 For nearly thirty years, successive governments have contributed to the erosion of the welfare state, chipped away at the public sector, denounced the "privileges" earned through social struggles in the twentieth century, and weakened the redistribution principles aimed at regulating socio-economic and geographic disparities. In academia and research, the so-called Pécresse law on the liberties and responsibilities of universities of 2007 (commonly referred to as LRU) was the cornerstone of a twofold, seemingly contradictory shift: the state's budgetary disengagement, reflecting a neoliberal approach, and the authoritarian strategic management of research by the very same state. The rationale behind the law consists in having the ostentatious (budgetary) autonomy of universities serve as a smokescreen for the deregulation of job statuses, the generalization of competition at all levels and the increased dependence of research on economic and industrial interests, ultimately threatening the actual autonomy of research. This policy has been pursued with tenacity despite the warnings and demands of the research community, leading to the creation of multiple, supposedly independent agencies for evaluation and funding, promoting a culture of "performance", "results" and "excellence" while cutting back on the laboratories' running funds to implement a targeted distribution of resources, largely defined by economic fluctuations (if not trends) as well as by preestablished hierarchies and situations. By promoting project-dependent funding, it has widened inequalities of resources between researchers and caused an immense waste of energy and public money, with countless hours lost to the evaluation or writing of projects to secure hypothetical funds - time that could have been spent on research or teaching.

3 To say the least, those in power have a morbid obsession with international rankings, which were introduced to promote the US/UK model of universities run as businesses, i.e., operating with their own funds (and relying on increasingly high tuition fees), at the cost of sacrificing operating budgets and the quality of teaching. Since the LRU law, the allegedly inadequate rankings of French universities have been regularly invoked to disparage researchers and pursue the liberalization of higher education and research further against their will. This has happened against a backdrop of drastic budgetary austerity: proportionally to the number of students, the higher education budget has dropped by over $10 \%$ since 2010 , and despite the promises repeated by all governments for twenty years to devote $1 \%$ of GDP to public research, the budget is still stuck at $0.8 \%$ (i.e., short 6 billion euros, an amount lower than the research tax credit, a tax exemption offered to large industrial and service sector groups). As a result, researchers and academics in France are both overworked and facing degraded living and working conditions. They are placed in increasingly precarious situations for increasingly long periods of time, being hired at the age of 35 on average. Austerity policies have also led to punishing losses of income: in thirty years, permanent staff have seen their purchasing power drop by $30 \%$, falling sharply behind the private sector, and precarious workers are faced with a great vulnerability, with short-term contracts succeeded by periods of uncertainty, and casual teaching stints currently paid below minimum wage. Everyone is increasingly evaluated according to purely quantitative criteria - number of publications, contracts secured or patents issued, with no consideration whatsoever for their actual contribution to scholarship. These 
rationales have encouraged the rise of "career entrepreneurs", to the detriment of fundamental, collective and genuinely independent research.

The measures announced for the LPPR law keep doggedly pursuing the neoliberal transformations launched since the early 2000s in the wake of the European Council's Lisbon Agenda, and are intended to amplify their impact. Their watchwords are as ever borrowed from managerial language: competitiveness, project-based funding, inegalitarian concentration of resources, budgetary austerity, leading to the spread of precarious employment and the generalization of competition between individuals, laboratories, universities, etc. As the CEO of the national centre for research CNRS Antoine Petit bluntly put it in November 2019, an "inegalitarian and Darwinian" reform is in the works. Widespread competition and the concentration of resources on a minority of institutions and individuals deemed to "perform" well according to managerial criteria have become the core principles of the governance of higher education and research, designed to tackle "societal challenges" that often reflect policy priorities. Yet, numerous studies have demonstrated the deleterious effects of such policies on the originality of scholarship and on the quality of the courses offered to students. This results in the "Matthew effect", a process through which those best endowed accrue further advantages, in the standardization of research, in bureaucratization, in the weakening of academic autonomy, the impoverishment of disciplinary diversity, etc.

This policy entirely disregards what researchers know from experience: in all disciplines, scientific work requires time and intellectual availability, which is incompatible with the anxiety resulting from sometimes radical precarity and the growing fragmentation of tasks. Science works better when teams are cohesive, but exacerbated competition between peers threatens their unity; it requires a critical distance that is hindered by dependence on administrative hierarchies. The academic community therefore wholeheartedly demands both a budgetary commitment that rises to the oncoming challenges (at least meeting the objective of devoting $1 \%$ of GDP to public research) and an equitable distribution of resources to staff who should be given civil servant status, as this still remains the condition of their independence and of the sincerity of research findings.

\section{Scientific journals: an efficient knowledge economy}

6 Against this backdrop, our scientific journals play a distinctive, paradoxical role. They are venues where an intense collective, productive work is performed, and effective outlets for the dissemination of scholarship, but they tend to be instrumentalized and mobilized in support of the dominant neo-managerial vision of research. The evaluation of scholars, laboratories and universities now largely relies on a count of papers published in our journals, based on bibliometric calculations whose weaknesses and adverse effects on science have been abundantly documented ${ }^{3}$. This isn't the least of the paradoxes of the current reforms: more than ever, they put journals at the centre of this approach to research focused on bibliometric "excellence", but in doing so, they contribute to fragilizing their operation, and to altering their scientific production processes.

7 This is why, by disrupting or interrupting our activities, by refusing to keep our distance from events affecting the scientific community and the social world beyond, 
we intend to highlight what our journals are made of, as well as the men and women who make them. Indeed, our collective intellectual and editorial work, allowing for the production and sharing of scholarship, is directly threatened by the current pending bills, which are slated to further weaken the public service of higher education and research.

The existence of our journals rests on a fragile, but efficient economy of knowledge. Scholars, many of whom are public agents, evaluate, discuss, accept or turn down texts on the basis of in-depth expertise, make suggestions to the authors so that these papers are more relevant, more comprehensive, and better argued. At the end of this long editing, discussion and rewriting process, involving collective deliberations and backand-forth exchanges with the authors, they publish and disseminate the texts most likely to contribute to our collective knowledge in the form of scientific papers. Additionally, these texts benefit from a painstaking work of formal verification, formatting and uploading, carried out sometimes by researchers, and sometimes by trained professionals in the fields of documentation, edition and/or digital publishing, under varied working arrangements - they may be civil servants, employed on fixedterm contracts or micro-entrepreneurs. Lastly, university libraries, which are public institutions, are the main purchasers of these journals, individually or in packaged form via digital platforms. This digital offer is free to students, teaching and research staff, and, in the case of free access journals, to all. It allows for the wide dissemination of the latest scientific advances beyond the academic field: thanks to the patient, collective work of scholarly journals, teachers, journalists, community actors, elected representatives and citizens benefit from a substantial and steady flow of reliable, updated sources of knowledge.

As it happens, while this economy ensures the enrichment of our scholarship, it offers little in the way of financial profit, and its survival relies on an invisible infrastructure - that of the public service of research.

This public service, ideally, ensures that our editorial secretariats are staffed with trained, skilled professionals in stable positions.

This public service, ideally, offers networks or publishing outlets for the digitalization, archiving and promotion of papers.

This public service, ideally, allows for the existence of quality open-access, entirely free digital scientific journals.

13 Lastly, this public service, despite the slow degradation of the working conditions of academics in permanent positions and the growing precarity of young lecturers and researchers, continues to give us the time needed to serve on editorial boards, to put together issues, to read, evaluate and discuss submitted papers.

However, ultimately, what little income these journals yield isn't used to pay the scholars who help them exist on a day-to-day basis or the workers who make them. Most of this revenue in fact goes to the often private companies that disseminate these journals on scientific publication platforms, which are part of a very fragile publishing sector. Internationally and in disciplines beyond the human and social sciences, the situation is even more complex. These companies distribute much of the publishing work: on the one hand, they save on editing thanks to the free labour of contributing academics; on the other, to fund open access, they resort to the inversed "author pays" model. As a result, the scientific community and its public funds pay multiple times for 
an activity whose profits are eventually reaped by these predatory businesses. To counter this marketization of knowledge, some platforms and journals have over the past few years began offering full open access, at no expense to authors. These openaccess initiatives should be reinforced and financially supported by public authorities for an even wider dissemination of scholarship.

The LPPR law is bound to undermine the foundations of the financial, scientific and human economy of our journals. It will hit the so-called research support personnel especially hard - the very individuals who enable the existence of journals as objects, manufactured products (even in digital form, a paper must comply with specific typographic, bibliographic, layout and uploading standards). It will plunge these personnel into precarity, replacing stable jobs by project-based contracts, which will force our journals to sap their forces by spending countless hours on burdensome applications to be allowed to employ a publishing professional for a few hours. This is part of a cynical effort to drastically lower employment among invisible personnel in the editorial chain (editors, editorial secretaries, translators, graphic designers, developers, printers and staffers of digital publication platforms, etc.). Indeed, among this personnel, very few individuals are hired under an open-ended contract or with civil servant status and their work is often made difficult by understaffing and by the relentless flow of publications, especially as tasks increasingly tend to be "pooled" between publications, doubling or sometimes tripling the workload in each position. Those forced to juggle poorly paid fixed-term contracts also end up having to work much more than the hours for which they are effectively paid. They alternate between periods of unemployment and stints in barely formed teams where they hardly have time to fit in. This is the current plight of OpenEdition's staff, which includes $60 \%$ of contract employees, and in some cases service providers, even though the platform has become indispensable to most of our journals ${ }^{4}$. The consequences of this system have already been documented in cases such as the national telecommunications company France-Télécom, the postal service (La Poste) and public hospitals: work overload, deterioration of working conditions and terms of employment, causing suffering, constant uncertainty, loss of meaning and waste of skills.

16 Lastly, by promoting project-based research drawing on short-term contracts and drastically reducing hires of permanent researchers, the LPPR will radically narrow the horizons of young unemployed researchers, forced to accumulate fixed-ended post-doc positions to make a living, to leave France to go wherever better positions are offered, or even to give up research altogether and pursue a career in a different field. These young researchers are the very same ones who contribute massively to the production of scientific papers and updated scholarship.

\section{Defending the autonomy of research and scientific publishing}

17 As previously stated, the work done in our journals is a painstaking process of discussion, and even - we dare say, despite the current uses of the word - of evaluation based on shared criteria. The transparency and intelligibility of the editorial process, and then the evaluation, acceptance or rejection of papers, have major implications on the trajectories of scholars and academics, especially those seeking employment, and the role played by journals in this process is undeniable. Although some would like to 
see these as perfect tools for "inegalitarian and Darwinian" selection, our journals are not rating agencies designed to grade scholars, to hierarchize "talents" or to measure "performance". Indeed, our evaluation processes are collegial, settled through deliberation in collectives seeking to produce the most precise, robust, best demonstrated scholarship. While they do not accept all submitted articles, our journals are not venues for elimination implementing criteria of "excellence" set by some bureaucracy: they are venues for reflection and appreciation, and for communication with the authors, to define how to best frame their scientific contributions. Be they generalist, specialized or interdisciplinary outlets, they inform the scholarly community and beyond about ongoing research, but they also raise new questions, propose new analyses or interpretations, and spark controversies. In the vast ecosystem of academic journals, each publication strives to develop an editorial line that reflects its own identity, and that cannot be reduced to a homogeneous conception of what is scientific. Ultimately, drawing as it does on collective practices and on a cooperative and cumulative approach to scientific research, the spirit of our journals is entirely at odds with the ideas of competition across the board and of the illusory individual evaluation of researchers.

18 In light of this, the coexistence of different journals is indispensable: plurality and emulation are the conditions for the debate and confrontation needed for the advancement and validation of knowledge. Science benefits from contradiction, from the multiplicity of approaches and schools of thought, and this is precisely threatened by the ongoing concentration of resources. At odds with a managerial approach, aimed at turning journals into centres for the selection and filing of a globally uniformized science, we argue that the ability of journals (especially at national level) to defend a distinctive scientific point of view, a line of their own, allows the existence of an international space of points of view, where the diversity of approaches is a condition of the dynamic of science. Academic journals are venues for the production and dissemination of a collectively certified research. The papers and special issues they publish are the outcome of original work: in the human and social sciences, months of archive or field research can be presented in 50,000 precious characters. This process of evaluation, collective deliberation and back-and-forth between editorial boards and authors takes many months of work, and few articles are ever published in their original version. Authors, reviewers, editorial board members and editorial secretaries all work together to produce reliable and accessible scholarship. As spaces for the transmission, translation and production of ideas, for encounters and debates, our journals continue to ensure the existence of scientifically sound and intellectually free scholarship, protected from private interests. They help make science better.

The academic world is already highly competitive as it is. To strengthen the quality and diversity of its output, social Darwinism is not what is needed. We need stable working spaces, and the structured environments without which the risk-taking, cooperation and debate that are indispensable for the production and consolidation of knowledge cannot happen. The series of reforms that includes the LPPR serves only to destabilize and impoverish the fragile ecosystem of our journals, by imposing constant structural changes, a vertical, project-based governance, requiring ever faster, short-term procedures and worsening the precarity of workers and collectives at work.

By resorting to such unprecedented actions as going on strike, joining the struggle with our colleagues, releasing blank issues or contributing to the ongoing social movement 
by publishing collective texts or anonymous testimonies, our journals are fighting the degradation of the public service of research and expressing their anger and concern. We want to reveal what is going on behind the scenes, and to point out what makes it possible to produce and disseminate scholarship that is independent (especially from industrial funding), reliable (verified by high-level academics) and innovative (serving as material for future academic and school handbooks). Our journals owe their entire existence to the public service of research. As the public service in general and the public service of research in particular are put at risk, we, the collective of journals joined in struggle, are taking a firm stand against the current reform projects. We refuse the destruction of the model of collaboration and solidary emulation that makes the French research community strong and proud.

\section{NOTES}

1. This issue was published online in the spring of 2020.

2. The reports were drafted by three working groups on the "funding of research", the "attractiveness of scientific jobs and careers" and "research partnership and innovation". They are available (in French) on the website of the Ministry for Higher Education, Research and Innovation.

3. Yves Gingras, Les Dérives de l'évaluation de la recherche. Du bon usage de la bibliométrie, Raisons d'agir, Paris, 2014.

4. See [https://academia.hypotheses.org/13060].

\section{AUTHORS}

\section{COLLECTIVE OF JOURNALS JOINED IN STRUGGLE}

As of 9 March 2020, two months into the movement, 147 journals had officially joined the struggle. They are listed here.

\section{CAMILLE NOÛS}

Laboratoire Cogitamus/Cogitamus Laboratory 